\title{
Reward Ceremony Scenes in Private Tombs of Post-Amarna Period in Thebes and Memphis
}

Emad Ghaly Osama Ibrahim

Faculty of Tourism and Hotels, Fayoum University

\begin{abstract}
The ancient Egyptian dreamed about being honored in life by his king, being mourned in death by his family and friends, and being welcomed in the hereafter by his gods. This paper studies and investigates the scenes of reward ceremony at five private tombs of post-Amarna period in Thebes and Memphis. The reward ceremony occurred during the lifetime of the tomb owner, who meant to record and immortalize it at his tomb.
\end{abstract}

Key words: Amarna, Memphis, Thebes, Private tombs, Reward, scenes, and Procession.

\section{Aim of the research}

The current paper investigates the reward scenes at private tombs of post-Amarna period in Thebes and Memphis, which are five tombs. It discusses the iconography and art style giving an ample description of the available scenes.

\section{Introduction}

"Take care of your tomb as the house of death is itself the house of eternal life", said an ancient Egyptian father to his faithful son. This well-said instruction was delivered from generation to generation in ancient Egypt. It reflects the significance of the tomb in Ancient Egypt (Gardiner and Weigall, 1913). The death was considered to be just a bridge linking between the current life and the eternal life after death. It is not strange that tomb was called in Old Egyptian language (pr-nHH), which means house of eternity (Kanawati, 1988).

Each deceased should have previously made a selection of pictorials and scenes that he was eager to immortalize with him in the other life. According to ancient Egyptian beliefs, the resurrection of the deceased resembles the process of retrieving consciousness for one after being fainted. After coming to life, the person is supposed to ask some question trying to know everything about himself, his life, his position, his address, ... and etc. this is why the tomb owners used to record their names, titles, families, careers, daily life, religion, and any other thing that would be of significance for the deceased to have in the hereafter (Sadek, Lecture, 2010). They recorded and preserved anything that would guarantee the eternal life of the deceased (Nash, 1909; Kanawati, 2001).

The ancient Egyptians gave special interest to their tombs. The walls of each tomb were richly decorated; hence they bear a wealth of ancient Egyptian art of the period, when they were installed. The private tombs are considered to be complete record of both secular and religious life in ancient Egypt. Those private tombs are more significant than the royal ones when it comes to talk about a record of daily life in ancient Egypt. The wall scenes of private tombs give informative pages on the book of ancient Egyptian civilization. The scenes reflect historical, religious, and social background of each of those high ranked officials.

Tomb scenes are considered to be one of the main sources by which scholars can study the artwork, art style, workmanship, workshops of art, daily practices, funerary practices, rituals, offerings, and religion of each location.

Thebes and Memphis were significant cities for living and for death as well (Rhind, 1862; Jeffreys and Smith, 1986). They were two main capitals and administrative cities. The Kings of Old Kingdom Egypt were buried in Memphis necropolis, while the kings of New Kingdom Egypt were buried in Theban necropolis. For the reason that; the Kings played an important role 
linking the people with deities through the ancient Egyptian civilization, hence the elites benefited getting spots very close to the royal burials and their funerary temples (Gabolde, 1995). The private tombs of Thebes are rock-cut funerary chapels, while the Memphite private tombs are temple-tombs.

"Post-Amarna period" is the name given to the period, which extended since the death of Akhenaten till the first third of Ramases II (c. 1335-1270 B.C.) (Dijk, 1986). Post-Amarna period is the transitional period between the art of Amarna period and the art of the Ramesside era. The period of study (Post-Amarna period) contains four sub-eras. Kaiser-Go has suggested the four sub divisions of the Post-Amarna Period based on their dates at PM and TN (Kiser-Go, 2006). This study will follow up same divisions.

\section{Reward scenes}

Reward ceremony is one of the most secular events, which the tomb owner meant to include in his tomb scenes. This study focuses on the iconographic analysis of reward ceremony scenes in private tombs of post-Amarna period. The following table shows the five-targeted group of tombs, their main location, and their sub-eras.

Table 1: Tombs including reward scenes.

\begin{tabular}{|c|c|c|c|c|}
\hline No & Tomb & City & Era & Sub-Era \\
\hline 1 & Horemheb Generalissimo & Memphis & \multirow{5}{*}{$\begin{array}{l}\text { Post-Amarna } \\
\text { Era/Period }\end{array}$} & A \\
\hline 2 & Amenhotep c Huy TT 40 & \multirow{4}{*}{ Thebes } & & A \\
\hline 3 & Neferhotep TT 49 & & & A \\
\hline 4 & Amenemope TT 41 & & & $\mathrm{~B}$ \\
\hline 5 & Neferhotep 50 & & & $\mathrm{D}$ \\
\hline
\end{tabular}

The cases listed below are presented in approximate chronological order.

\section{1- Memphite Tomb of the Generalissimo Horemheb}

Table 2: Memphite Tomb of Horemheb

\begin{tabular}{|l|l|}
\hline Tomb Owner & Horemheb (Porter and Moss, 1927-1951). \\
\hline Principal Title & Generalissimo (Martin, 1989). \\
\hline Date of Tomb & Akhenaten - Tutankhamen - Ay (Martin, 1976). \\
\hline Number of Tomb & BMS04/nn (Bresciani and Giammarusti, 2003). \\
\hline Location of Tomb & $\begin{array}{l}\text { About 500 m to the south of step pyramid of King Zoser (Martin, } \\
\text { 1989). }\end{array}$ \\
\hline Location of Scene & $\begin{array}{l}\text { (Outer Court, South Wall), (Outer Court, North Wall), and (Inner } \\
\text { Court) (Plan 1). }\end{array}$ \\
\hline
\end{tabular}

The Upper portions of all walls are missed. Only the lower registers could survive (Fig. 1). Outer Court, South Wall:

The scenes start from east to west.

- Upper Register; shows the lower part of Horemheb wearing sandals and ceremonial long garment. He is supposed to be in adoration position before an enshrined god, but the scene is missed (Martin, 1989).

- Lower register; Horemheb is being rewarded and debuted before the king on the right and before representatives of foreign nations on the left. The upper part of the scene is damaged; hence the king can't be easily known. Dijk suggests that the king here supposed to be Ay based on the fact that Tutankhamen is represented at the inner courtyard, which might have 
been built before the outer courtyard that must have been built during the reign of Ay (Dijk, 1993). The King and Horemheb are represented in larger scales, while the foreign people are represented in lower scales. The foreign people are clad in their costumes. They are represented with long hair, headbands, heavy beards, and bare feet. They bent in a gesture of respect before the reward scene (Fig. 2) (Martin, 1989).

- Appearance window; remains of appearance window can be seen on the upper register. Martin suggests that the royal representations here are attributed to King Ay and his wife for the same reasons which Dijk suggested. Traces of chariot and charioteer can be noticed. On the lower register one can distinguish two horses (Fig. 2) (Martin, 1989).

- Scene in two registers. The upper register is badly damaged. It depicts the King (supposed to be Ay) with his wife on the appearance window/balcony of the royal palace of Memphis. The king and his wife watch the reward ceremony of Horemheb, who is represented before a table loaded of rewards, collars, and amulets. Immediately under the window of appearance there is a representation of Nile god Hapy forms the unification of the two lands with symbol of unification (sm3-t3wy). The lower is well reserved. It shows representatives of the foreign countries attending the reward ceremony of Horemheb. They are represented while acclaiming the king on his balcony. They are arranged on the left and on the right flanking (sm3-t3wy) sign and two tables loaded of merits, medals, and collars. They are clad in costumes differ from the Egyptian traditional costumes (Fig. 3) (Martin, 1991 ).

- Lower part of a scene depicting female figure (supposed to be wife of Horemheb) before a vessel placed upon three-legged stand. The tight long dress can be seen behind her bare feet. The nail is finely represented. The pointed heel is inspired from Amrana art (Fig. 4) (Martin, 1989).

Outer Court, North Wall:

The scenes start from west to east (near the eastern end of the wall).

- A representation of male figure (supposed to be either Ay or Horemheb) clad in long pleated tunic with fringed sash kilt (Martin, 1989). He holds a long staff, while watching the reward scene of (unknown) high official. The high official is represented, while raising his hands. Some servants fix the collars and honors for him. There are amphorae and piles of food on upper level at the background. The high official is represented with cone of perfume, curly wig, headband, big round earring with six pendent stings, and long pleated tunic. This scene can be compared with similar scenes at Amarna temples and tombs (Fig. 5) (Martin, 1989).

Inner Court, South Wall:

- On the right hand, King Tutankhamen and his wife are represented in sitting position upon animal-legged thrones. The royal couple wears sandals on feet, which rest upon cushions. There must have been a shrine or pergola upon their heads, which is missed nowadays. The upper part of the King and the Queen is destroyed, but Tutankhamen supposed to hold the royal scepters, while his wife is supposed to hold a bowl or a present for Horemheb. An officer with short staff stands on a ram leading downwards from the royal throne toward Horemheb. The officer is represented with long ceremonial tunic, triangular apron, and bare feet. The background is full of bouquets of flowers, collars, honors, and gifts (Fig. 6) (Martin, 1989).

- The reward scene of Horemheb, who is represented in large scale standing in the middle. He looks towards the King and the Queen, while raising his arms up. Horemheb is represented with long perfume cone, headband, later added cobra, long wig, ceremonial tunic, sash kilt, 
and sandals. His neck is loaded with collars. Two courtiers fixing the collars and honors for Horemheb. Three attendants bend forward, while bringing a long perfume cone and two more collars. A scribe with scribal equipment stands on the middle register bringing the captives into the presence of the royal couple immediately behind the commander-in-chief. The uppermost sub-register depicts high officials and courtiers attending the reward ceremony of Horemheb, while holding ceremonial fans. They are represented with ceremonial tunics, sash kilts, and bare feet (Fig. 7) (Martin, 1989).

- Scene of captives in three registers. The first register, four scribes can be seen while recording details. The rest of the register shows only the lower part of horses, mules, chariots, and charioteers. Second register, Egyptian soldier squats before the royal couple and Horemheb, while holding the rope in which all captives are tied firmly. Third register starts with two Egyptian soldiers waiving hands to salute the royal couple and Horemheb, and then line of Western Asiatic captives. All captives on second and third registers are shackled by means of rope and wooden manacles. The captives of this register are Western Asiatic people of different ages and different tribes. Each figure is a masterpiece in itself. Along the wall one can see aged prisoners, young prisoners, male captives, female captives, children, different hairstyles, different costumes (Fig. 8) (Martin, 1989).

About the added cobra on the forehead of Horemheb: It has been suggested that; First, the cobras were added on the forehead of Horemeheb after becoming the king of Egypt by officials, who apparently were neglectful, as they added cobras on some scenes and neglected adding to the rest of scenes. Second, the cobras were added after the death of King Horemheb, as he was defied and worshipped in Memphis till the Ramesside period (Martin, 1989).

\section{2- Theban Tomb of Amenhotep called Huy TT 40}

Table 3: Tomb of Amenhotep called Huy TT 40

\begin{tabular}{|l|l|}
\hline Tomb Owner & Amenhotep also known as Huy (Porter and Moss, 1927-1951). \\
\hline Principal Title & $\begin{array}{l}\text { Vizier, and then viceroy of Kush (Porter and Moss, 1927-1951; } \\
\text { Davies and Gardiner, 1926; Kiser-Go, 2006). }\end{array}$ \\
\hline Date of Tomb & Tutankhamen (Kampp, 1996; Kiser-Go, 2006). \\
\hline Number of Tomb & TT 40 (Kampp, 1996). \\
\hline Location of Tomb & Qurnet Murai (Porter and Moss, 1927-1951; Kampp, 1996). \\
\hline Location of Scene & Northern Side, East Wall (Plan 2). \\
\hline
\end{tabular}

Northern Side, East Wall (Fig. 9) (Davies and Gardiner, 1926): The scene is on the south:

King Tutankhamen is represented in a kiosk, which is surmounted by Egyptian cornice and a frieze of cobras and solar disks. King Tutankhamen is depicted while siting on a low-back throne with all signs of royalty. He wears the xprS crown with cobra on his forehead. He wears collars and holds crook and flail by the left hand while the right hand holds anx sign. King Tutankhamen wears long pleated garment, which reaches his ankles and oxtail. He wears the sandal and his feet rest upon a pedestal. The sign of sm3-t3wy is well represented on the throne. Traces of a courtier can be seen before Tutankhamen.

Rest of the Eastern Wall (Fig. 10) (Porter and Moss, 1927-1951; Davies and Gardiner, 1926):

The reset of the scene represents standing figure of Huy in a large scale surrounded by many incidents in three registers behind Huy and four before him.

Behind Huy:

- First register; high official with a roll of papyrus announces the appointment of Huy before Tutankhamen. Both of them stand with bare feet. Huy is represented while bearing a fan, 
which was one of his titles (fan bearer to the right of the king) (Davies and Gardiner, 1926). Four courtiers following Huy, represented in dark skin and long black curly wigs while wearing white costumes and white sandals.

- Second register; Huy receives the office seal, and then receives his official ring. Two sons of Huy are represented carrying bunches of foliage and flower bouquets, while following their father Huy in large-scale.

- Third register; Huy and his family followed by friends and the rest of the procession, which will be described below.

The large-scale representation of Huy while coming back from the palace of Tutankhamen followed by two of his sons in lower scale. Huy carries two bouquets. He is depicted in dark brown color with long black curly wig reaches his shoulder. He wears a collar of three rows of beads and two bracelets. He wears long ceremonial tunic, fringed sash kilt, and sandals.

Before Huy:

- First register; Huy kneeling, while being followed by two agents of Kush then two servants holding flowers. There are parts of destructed scenes of servants with two calves.

- Second register, a row of five servants with bare feet carrying flowers and bunches of foliage. Two servants facing right and welcoming Huy, while the other three facing left.

- Third register, a procession of courtiers, sailors, and officials headed by two servants.

- Fourth register, a procession begins with offering and flower bearers, lute player, clappers, dancers, and soldiers.

The lower register is damaged. It shows cattle, goats, horses, and donkeys (Fig. 10).

\section{3- Theban Tomb of Neferhotep TT 49}

Table 4: Tomb of Neferhotep TT 49

\begin{tabular}{|l|l|}
\hline Tomb Owner & Neferhotep (Kampp, 1996). \\
\hline Principal Title & $\begin{array}{l}\text { Chief scribe of Amun (Porter and Moss, 1927-1951; Davies, 1933; } \\
\text { Kiser-Go, 2006). }\end{array}$ \\
\hline Date of Tomb & $\begin{array}{l}\text { Ay (Porter and Moss, 1927-1951; Davies, 1993) only or } \\
\text { Tutankhamen, Ay, and Horemheb (wikipedia, Sep. 25 2014). }\end{array}$ \\
\hline Number of Tomb & TT 49 (Porter and Moss, 1927-1951). \\
\hline Location of Tomb & Khokha (Kampp, 1996). \\
\hline Location of Scene & Transverse Hall, South Side, Western Wall (Plan 3) \\
\hline
\end{tabular}

Transverse Hall

South Side, Western Wall (Fig. 11):

- On the right, king Ay and his wife queen Ty are represented on the window/balcony of their palace attending the ceremony of rewarding Neferhotep. The scenes of the rewarding ceremony are represented in two registers. Fan bearers and courtiers are represented in two registers before the royal couple, showing the respectful and obedience gesture before the king. The upper register depicts high official and servants bringing produce toward the palace. The lower register shows the courtiers fixing the collars and honors for Neferhotep, who is represented in large scale at the middle of the scene, then high officials and servants bringing some honors, and then the gate of exit out of the palace (Porter and Moss, 1927-1951; Davies, 1993).

- On the Middle register: Neferhotep going back home on his chariot after being rewarded. The scene depicts the line of trees on the way back. A little child runs happily before him 
telling the news to the attendants, who welcome his advent with musical instruments celebrating the event (Fig. 11).

- On the left, wife Mrytre is represented returning home with gifts and servants, then MrytRe receiving rewards from the queen in the royal harîm (Porter and Moss, 1927-1951; Davies, 1993):

The lower register in two rows:

1- Banquet, servants bringing food from garden, and preparation of drinks.

2- Men bringing supplies to home, female dancers, tambourine players.

\section{4- Theban Tomb of Amenemope TT 41}

Table 5: Tomb of Amenemope TT 41

\begin{tabular}{|l|l|}
\hline Tomb Owner & Amenemope called Ipy (Porter and Moss, 1927-1951). \\
\hline Principal Title & High steward of Amun (Assman, 1991). \\
\hline Date of Tomb & Horemheb to Seti I (Assman, 1991). \\
\hline Number of Tomb & TT 41 (Porter and Moss, 1927-1951). \\
\hline Location of Tomb & Northern section of Sheikh Abd El-Qurna (Kiser-Go, 2006). \\
\hline Location of Scene & Transverse Hall, North Side, Eastern Wall (Plan 4) \\
\hline
\end{tabular}

Transverse Hall

North Side, East Wall:

The scenes are arranged in four registers:

- Upper register: Frieze of Hqr-Hqrw frames the upper part of the wall. Amenemope returning home on chariot surrounded by his followers, servants, friends, and household, who acclaim his return. The servants are in two sub-registers. Some of them carrying goods. Others carrying palm leaves and olive branches welcoming his advent. Amenemope is represented in larger scale wearing all his costumes with perfume cone. Amenemope might have returned home after being rewarded the golden collar he wears from god Amun. The scene of rewarding ceremony may have been deteriorated. On the left another large representation of Amenemope depicts him while entering his house. (Fig. 12) (Porter and Moss, 1927-1951; Assman, 1991).

\section{5- Theban Tomb of Neferhotep TT 50}

Table 6: Tomb of Neferhotep TT 50

\begin{tabular}{|c|c|}
\hline Tomb Owner & Neferhotep (Porter and Moss, 1927-1951). \\
\hline Principal Title & $\begin{array}{l}\text { - God's father of Amun-Re (Porter and Moss, 1927-1951; } \\
\text { Kiser-Go, 2006). }\end{array}$ \\
\hline Date of Tomb & $\begin{array}{l}\text { Horemheb (Porter and Moss, 1927-1951; Mond and W., Emery, } \\
\text { 1927), but some date it to Seti I and early Ramases II (Kiser-Go, } \\
\text { 2006). }\end{array}$ \\
\hline Number of Tomb & TT 50 (Porter and Moss, 1927-1951; Kampp, 1996). \\
\hline Location of Tomb & $\begin{array}{l}\text { Northern portion of Sheikh Abd El- Qurna (Bénédite, 1894; Hari, } \\
\text { 1985; Yoshimura et al, 1988; Kiser-Go, 2006). }\end{array}$ \\
\hline Location of Scene & Transverse Hall, South Side, South Wall (Plan 5) \\
\hline
\end{tabular}

Transverse Hall

South Side, Southern Wall (Porter and Moss, 1927-1951; Hari, 1985): 
The scenes are in two registers

- Upper Register: the scene shows rewarding ceremony of Neferhotep by king Horemheb. The rewarding ceremony is being done in three stages, which are finely merged into single scene. First, king Horemheb gives the order to the fan bearer "May" and courtiers, who bend forward as a greeting and sign of obedience before the king and the stand loaded of collars and merits. Two employees follow the king, while holding a staff ends with open lotus flower. Second, the courtiers deliver the reward to Neferhotep. Third, the father congratulates both of Neferhotep and Parennefer. Horemheb is represented in large scale wearing the xprS crown, two collars, bracelets, long ceremonial garment, royal kilt adorned with cobras, and sandals. Horemheb holds Hk3 and flail on his left hand. May is represented with long heavy wig, while the others are represented with shaven heads. The second stage represents two men dressing Neferhotep, who helps them raising his hands while they are fixing costumes and jewels. They are represented with shaven heads, long kilts, and bare feet. The last stage the father stands with shaven head, long knotted kilt, and bare feet to congratulate the two men (Fig. 13).

\section{Discussion and conclusions}

The art of Amarna didn't meet a sudden death after the fall of Amarna, but rather it continued to inspire artists in Thebes and Memphis during the post-Amarna period. The influences of Amarna art were very clear on scenes of private tombs of both Thebes and Memphis.

Three tombs of the current study (Horemheb, TT 40, and TT 49) belong to sub-era (A), in which the influences of Amarna and the subjects of Amarna are still very clear. The Amarna influences can be described as elongated skulls, long wrinkled neck, lazy eye, heart-shaped mouth, fleshy torso, full breast in male figures, paunch, and pointed heels. The Amarna subjects can be explained in representing the window of appearance or balcony, which was common in Amarna itself.

Theban tomb of Amenemope TT 41 is the only tomb of current study, which belongs to sub-era (B). The influences of Amarna are quite clear, which can be seen on depicting the road back to home very close to realism.

Current study doesn't include any tomb from sub-era (C), however it contains a single tomb from sub-era (D). The style of art of which is very close to the early Ramesside style of art. The figures became slimmer and longer than before.

Apparently, the rewarding of a person was an organized ceremony taking the following sequence in order.

- The royal couple in the balcony/window of appearance.

- The king gives an order to the courtiers and fan bearers to reward someone and they bend forward as a gesture of obedience.

- The royal scribes record the order and the event.

- The courtiers fix the collars, honors, and merits for the honored person.

- Some times the foreign peoples were allowed to attend the ceremony and to claim the rewarded one, who greets them.

- The tomb owner takes a chariot on the way back to his home loaded of collars after being rewarded.

- Family members and musical band welcome the advent of the rewarded person, while acclaiming him and celebrating the event.

- The celebration banquet in which one may see lots of goods and produce. 
Many persons were represented on reward ceremony scenes of private tombs in post-Amarna period i.e. king, queen, rewarded person, courtiers, fan bearers, scribes, employees, tributes, foreign peoples, servants, workers, family members, children, and musical bands.

King Ay was represented three times. He was represented twice at the Memphite tomb of Horemheb and once at Neferhotep TT 49. Tutankhamen was represented at the Memphite tomb of Horemheb and at TT 40 of Amenhotep called Huy. Horemheb was represented at his own tomb as a rewarded person once before king Tutankhamen and once before king Ay. It has been suggested that Horemeheb may have been represented in large scale attending the reward ceremony of an unknown employee (Fig. 5). Horemheb was represented as a king giving order for holding reward ceremony at TT 50 of Neferhotep.

Window of appearance was inspired from the art of Amarna. It was represented at Memphite tomb of Horemheb, TT 49 of Neferhotep, and TT 50 of Neferhotep.

Musical bands were represented with creativity on reward ceremony of both TT 40 of Amenhotep called Huy and TT 49 of Neferhotep. Family members and children participated actively on the reward scenes of both tombs.

In case of Horemheb, the unique thing is the creativity of artist depicting peoples from different countries and backgrounds. Each figure of those foreigners is masterpiece in itself.

In case of TT 40 of Amenhotep called Huy, the foreign tributes and Kushite people and agents were accurately depicted showing lots of details in human body and variety of styles of their costumes.

In case of TT 49 of Neferhotep, the line of trees on the road back to the house of Neferhotep is very close to realism. The other noteworthy scene is that of his wife Mrytre at her house and the scene of queen Ty while rewarding Mrytre in the royal harim on top left of the scene.

In case of TT 41 of Amenemope called Ipy, the servants welcomed his advent on a chariot back home while bearing palm leaves and olive branches.

In case of TT 50 of Neferhotep, the artist merged the three stages in a single scene making a great composition, which reflects the workmanship and the professionalism of the artist.

\section{References}

Assman J., Das Grab des Amenemope TT 41, 2 vols, Theben 3, Mainz am Rhein: Philipp von Zabern, 1991.

Bénédite G.,"Tombeau de Neferhotopou, Fils d'Amenemanit”, MMAF 5. Vol. 2, Paris: Leroux, 1894, pp. 489- 540.

Bresciani E., and Giammarusti A., The North Saqqara Archaeological Site Handbook for the Environmental Risk Analysis, in Fabrizio Ago et al, eds., Università di Pisa, Italy, 2003.

Davies N. de G. and Gardiner A. H., The Tomb of Huy, Viceroy of Nubia in the Reign of Tut'ankhamun (No. 40), EES, London, 1926.

Davies N. de G., The Tomb of Nefer-hotep at Thebes, Publications of MMA Expedition IX, New York, 1933.

Dijk J. V.,"The Development of the Memphite Necropolis in the Post-Amarna Period", in A-P. Zivie, ed., Memphis et Ses Nécropoles au Nouvelle Empire: Nouvelles Donées, Nouvelles Questions, Actes de Colloque International CNRS, Paris, (9 au 11 Octobre) 1986, pp. 37- 46.

Dijk J. V "'The New Kingdom Necropolis of Memphis; Historical and Iconographical Studies, Dissertation at University of Groningen, 1993. 
Gabolde L., “Autour de la Tombe 276: Pourquoi va-t-on se faire entrer à Gournet Mouraï au Debut du Nouvel Empire?", (Thebanische Beamtennekropolen) in J. Assmann, ed., SAGA 12, 1995, Heidelberg, pp. 155- 165.

Gardiner A. H. and Weigall A. E., A Topographical Catalogue of the Private Tombs of Thebes, London, 1913.

Hari R., Le Tombe Thébaine du Père Divin de Neferhotep (TT 50), Éditions de Belles-Lettres, CH 12-11 Genève 20, 1985, p. 6.

Jeffreys D. G. and Smith H. S.,"Memphis and the Nile in the New Kingdom: a Preliminary Attempt at a Historical Perspective", in A-P. Zivie, ed., Memphis et Ses Nécropoles au Nouvelle Empire: Nouvelles Donées, Nouvelles Questions, Actes de Colloque International CNRS, Paris, (9 au 11 Octobre) 1986, pp. 55- 66.

Kampp F., Die Thebanische Nekropole, Theban XIII, 2 vols., Mainz am Rhein, Philipp von Zabern, 1996.

Kanawati N., The Tomb and Beyond, Burial Customs of Egyptian Officials, WarminsterEngland, 2001.

Kanawati N., The Tomb and Its Significance in Ancient Egypt, Cairo, 1988.

Kiser-Go D., A Stylistic and Iconographic Analysis of Private Tombs of Post-Amarna Period Tombs at Thebes, Dissertation at UC Berkeley, 2006.

Lecture and presentation by Prof. A. Sadek, Institute of Coptic Studies, Cairo, Aug. 192010.

Martin G. T., The Memphite Tomb of Horemheb Commander of Chief of Tutaankhamoun, vol. I, (The Reliefs, Inscriptions, and Commentary), in A. B. Lloyd, ed., EES, London, 1989.

Martin G. T.,"Excavations at the Memphite Tomb of Horemheb, 1975; Preliminary Report”, JEA 62, EES, London, 1976, pp. 5- 13.

Kanawati N. The Hidden Tombs of Memphis; New Discoveries from the Time of Tutankamun and Ramasses the Great, London, 1991.

Mond R. and Emery W.,"Excavations at Sheikh Abd El Gurneh, 1925-1926”, LAAA 14, 1927, pp. 13- 34.

Nash W. L., "The Tombs of Ancient Egypt", The Scarab Club Papers I, 1909, pp. 5- 36.

Porter B. and Moss R., Topographical Bibliography of Ancient Egyptian Hieroglyphic Texts, Reliefs and Paintings, 7 vols., 1927-1951.

Rhind A. H., Thebes, Its Tombs and Their Tenants Ancient and Present, London, 1862, pp. 3059.

Yoshimura S. et al, Comparative Studies of Noble Tombs in Theban Necropolis, Waseda University, 1988.

http://en.wikipedia.org/wiki/TT49, Last accessed on Sep. 252014. 


\section{Plans and Figures}

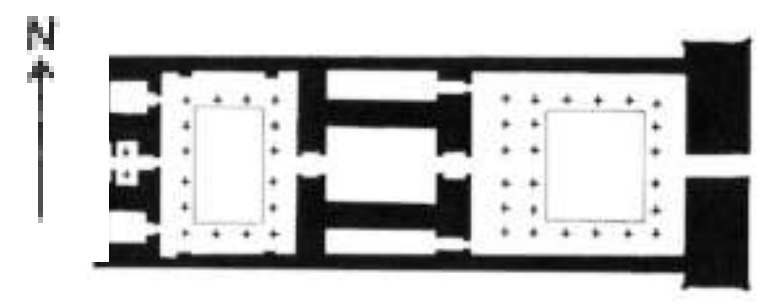

Plan 1

Plan of Horemheb Tomb

After G. T. Martin, The Memphite Tomb of Horemheb, pl. V.

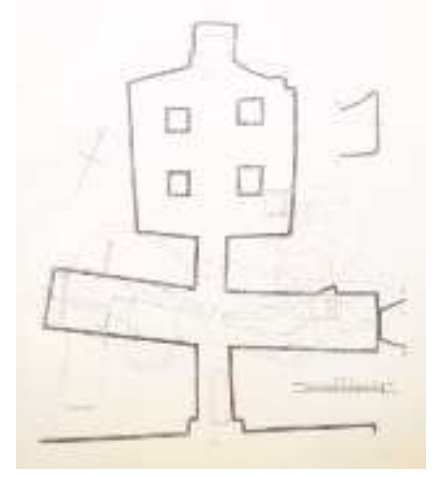

Plan 2

Plan of Amenhotep also called Huy Tomb (TT 40).

After N. de G. Davies and A. H. Gardiner,

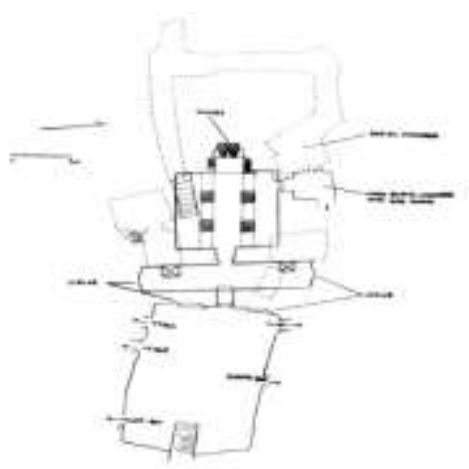

Plan. 3

Plan of (TT49) Neferhotep Tomb

After F. Kampp, TN I, p.

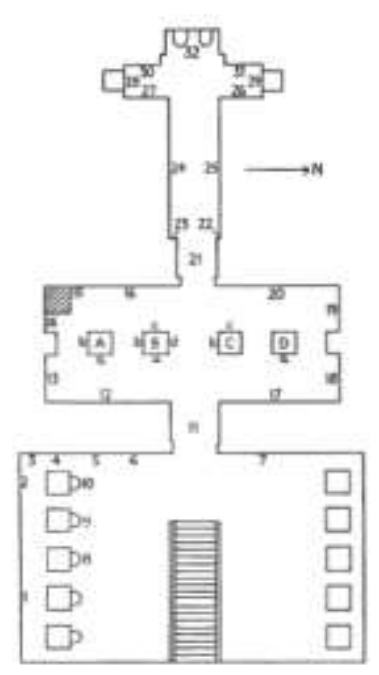

Plan 4

Plan of Amenemope also called Ipy TT 41

$\left(\mathrm{PM} \mathrm{I}^{2}\right.$, p. 80) 


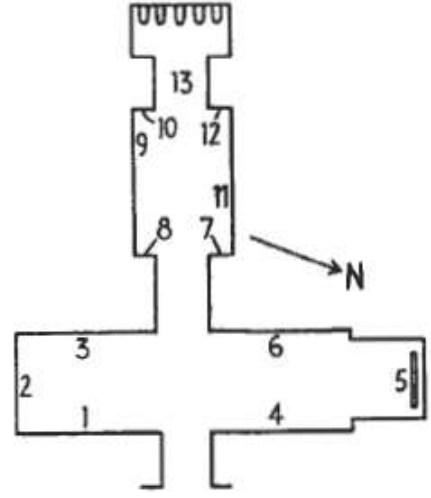

Plan 5

Plan of Neferhotep

Tomb TT 50

(PM I', p. 90.)

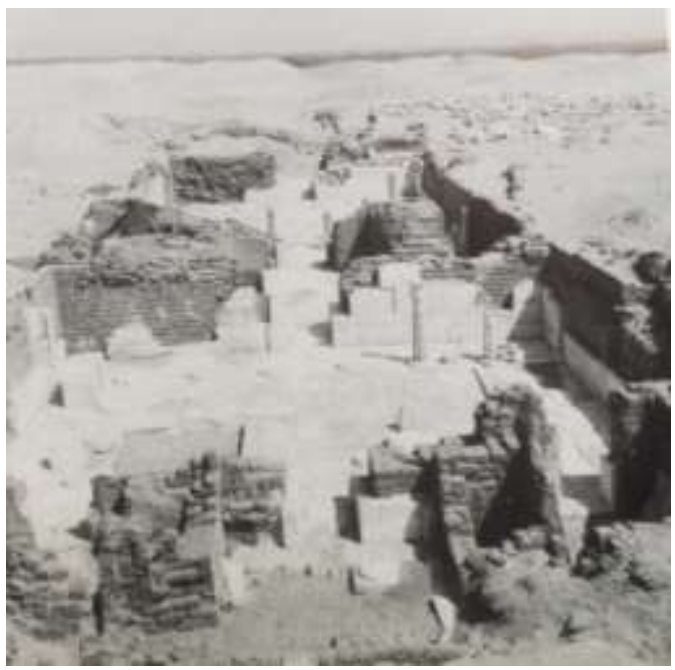

Fig. 1

Superstructure of Memphite Tomb of Horemheb

After G. T. Martin, The Memphite Tomb of Horemheb, pl. 6.

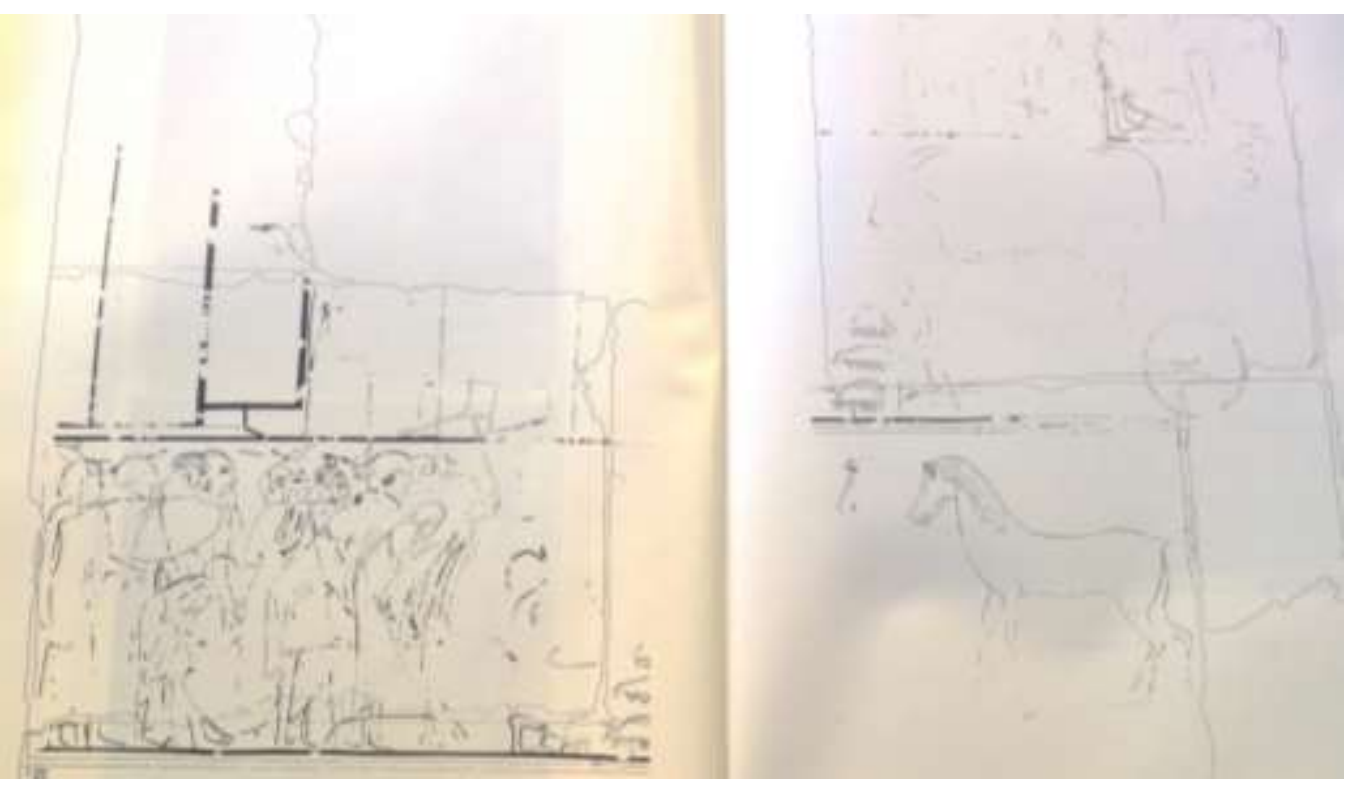

Fig. 2

South Wall, Outer Courtyard, Memphite Tomb of Horemheb 


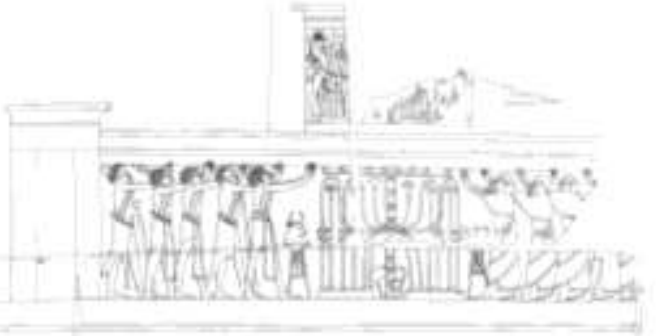

Fig. 3

Appearance Window, Tomb of Horemheb

After G. T. Martin, The Hidden Tombs of Memphis, p. 49.

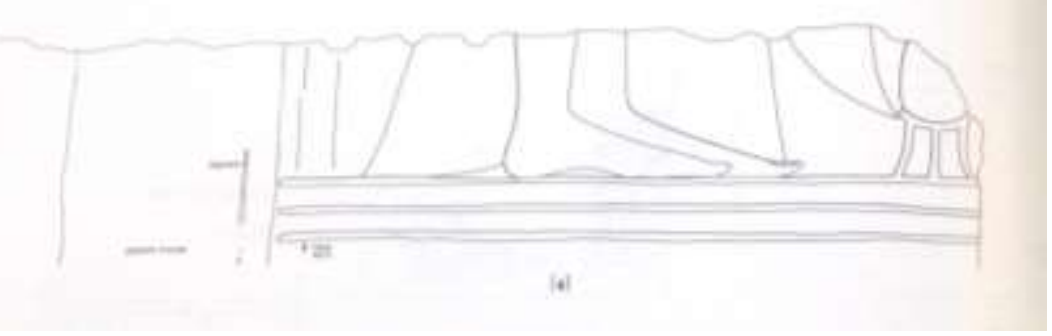

Fig. 4

South Wall, Outer Courtyard, Memphite Tomb of Horemheb

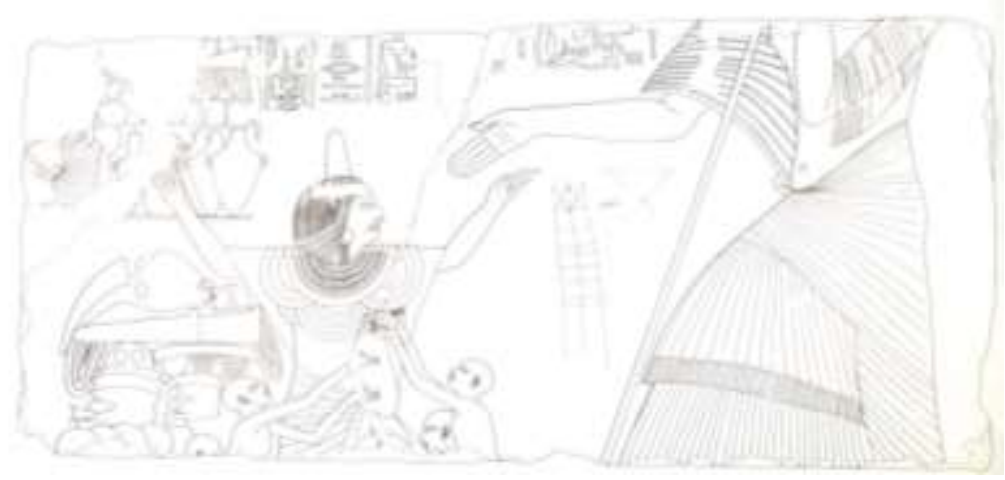

Fig. 5

Reward Scene, North Wall, Outer Courtyard, Tomb of Horemheb. 
International Journal of Heritage, Tourism and Hospitality Vol. (11), No. (1/2), March, 2017 By: Faculty of Tourism and Hotels, Fayoum University
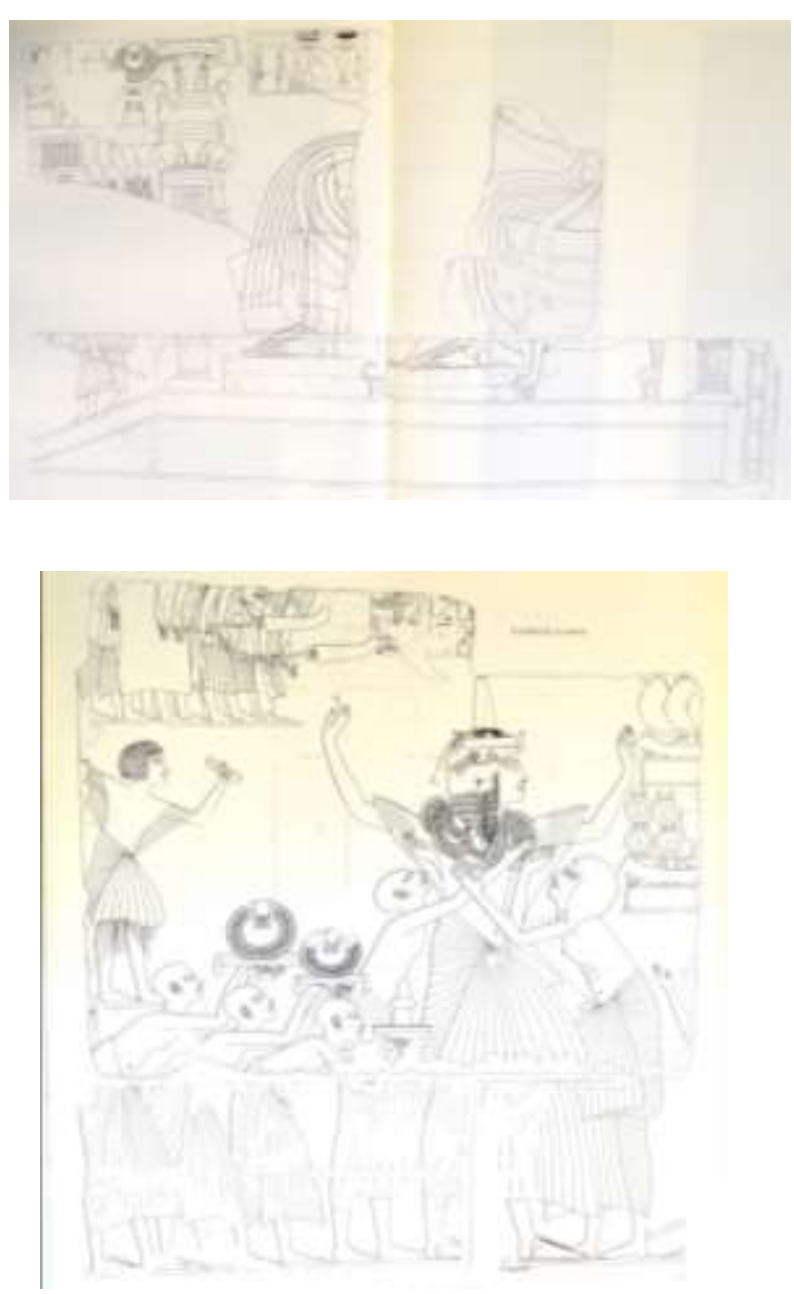

Fig. 6

Tutankhamen and his wife, South SideSouth Wall, Second Courtyard, Tomb of Horemheb.

After G. T. Martin, The Memphite Tomb of Horemheb, pl. 108.

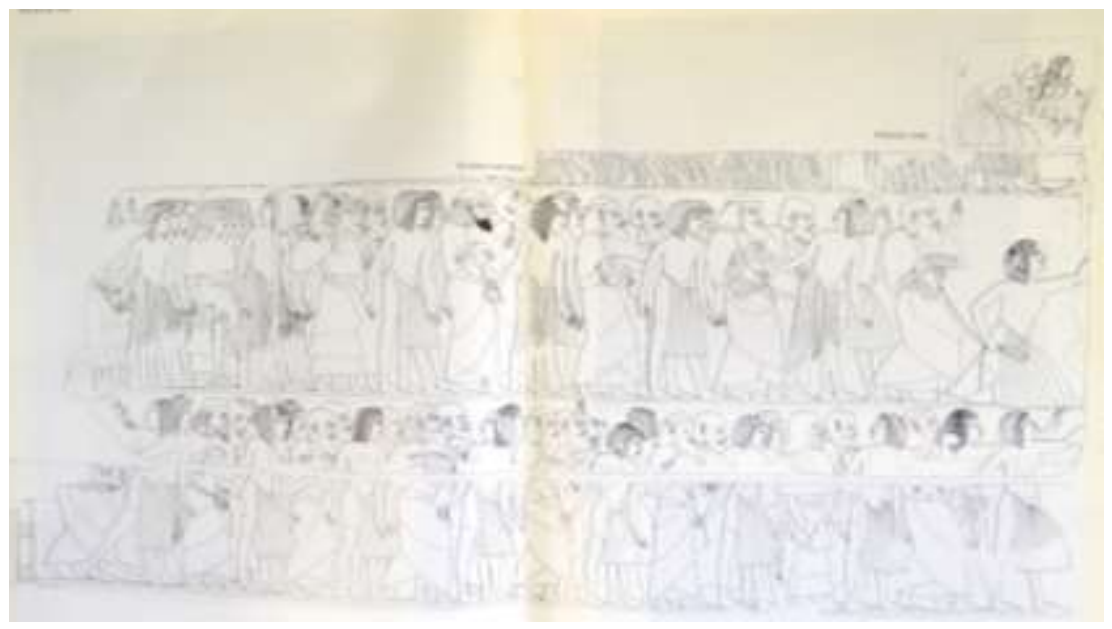

Fig. 8

South Side-South Wall, Second Courtyard, Tomb of Horemheb.

After G. T. Martin, The Memphite Tomb of Horemheb, pl. 105. 
International Journal of Heritage, Tourism and Hospitality Vol. (11), No. (1/2), March, 2017 By: Faculty of Tourism and Hotels, Fayoum University

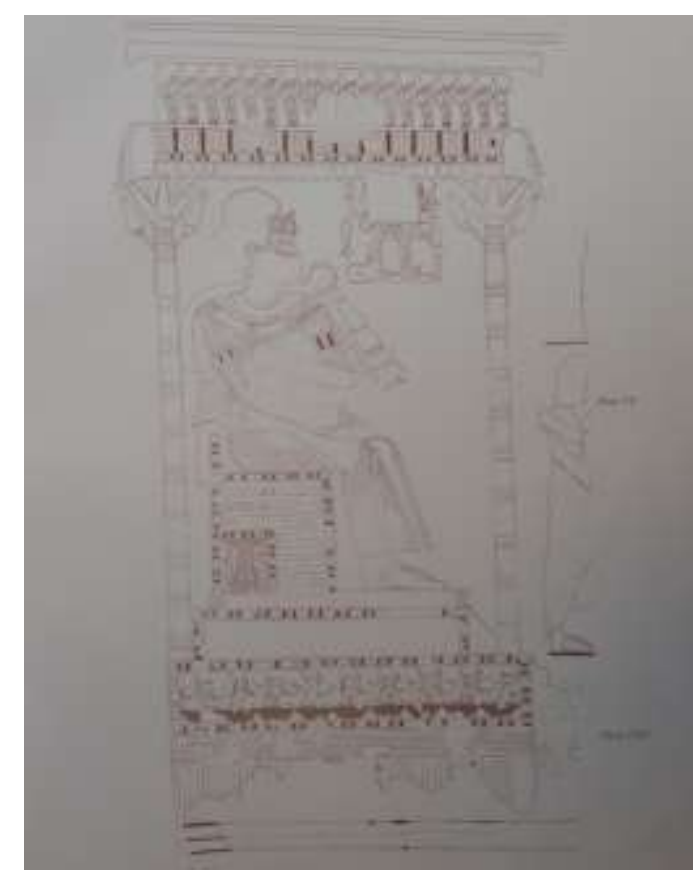

Fig. 9

Tutankhamen, Northern Side, East Wall, Transverse Hall, Huy's Tomb

(TT 40)

After Nina de G. Davies and A. H. Gardiner, The Tomb of Huy, pl. IV.

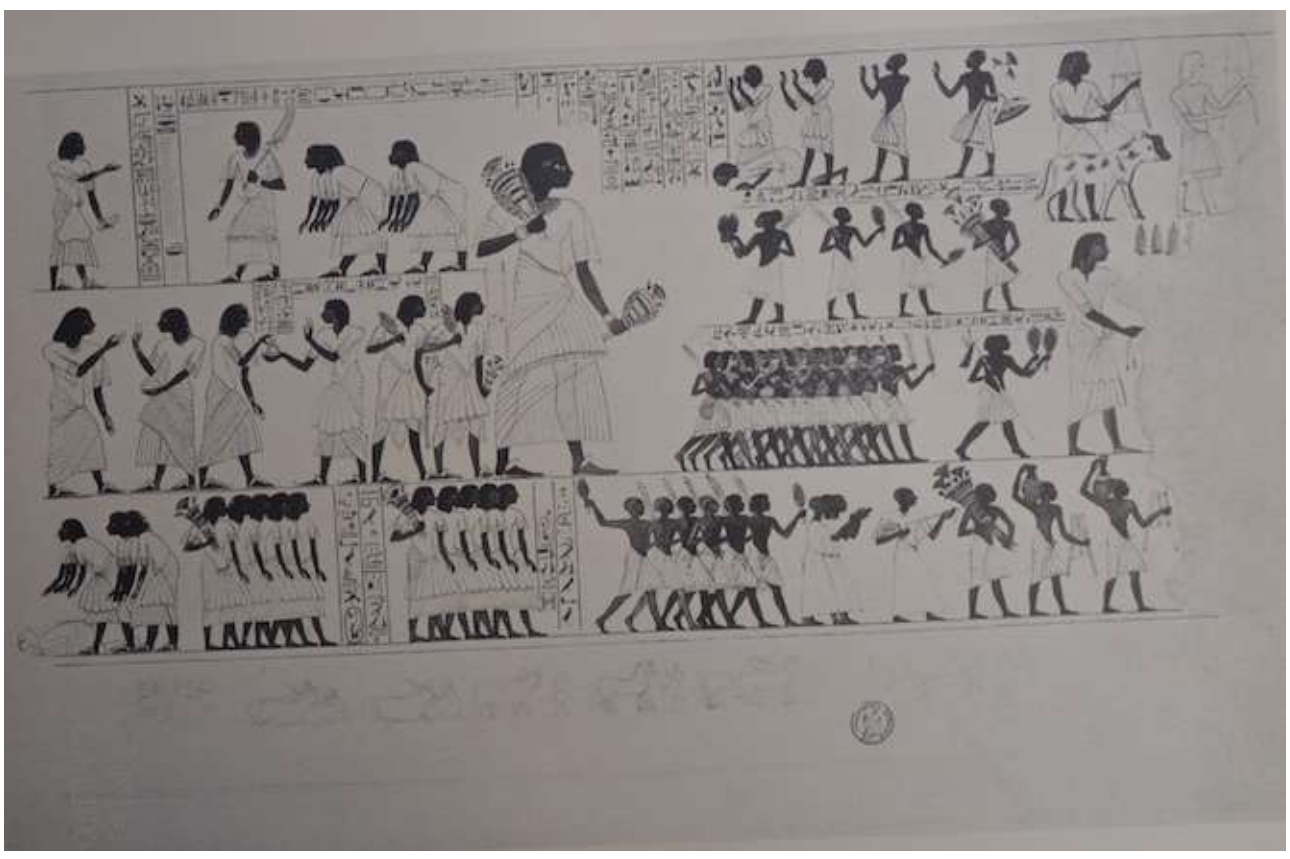

Fig. 10

Northern Side, East Wall, Transverse Hall, Huy's Tomb (TT 40)

After Nina de G. Davies and A. H. Gardiner, The Tomb of Huy, pl. V. 


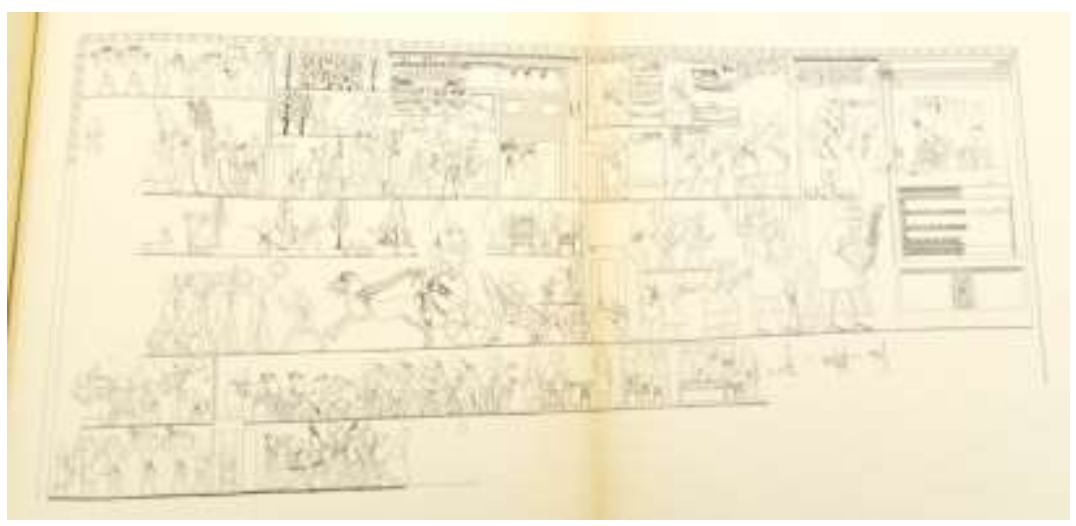

Fig. 11

South Side, Western Wall, Vestibule of Neferhotep Tomb (TT 49)

After N. Davies, The Tomb of Nefer-hotep, Vol. II, pl. I

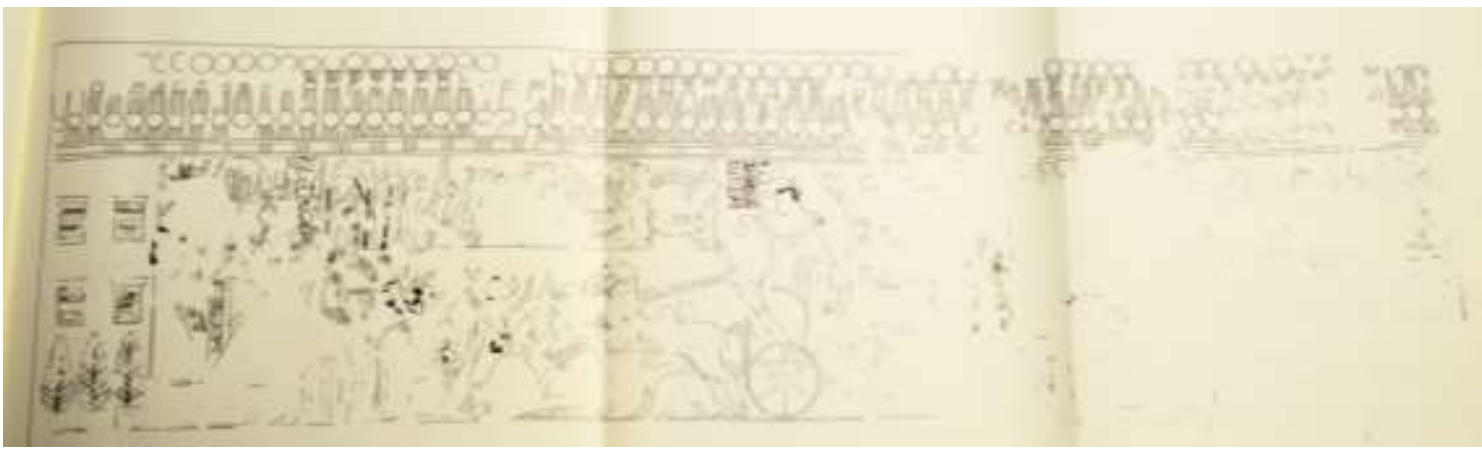

Fig. 12

Amenemope Returning Home on Chariot, TT 41

After J. Assman, Das Grab des Amenemope, pl. 31.

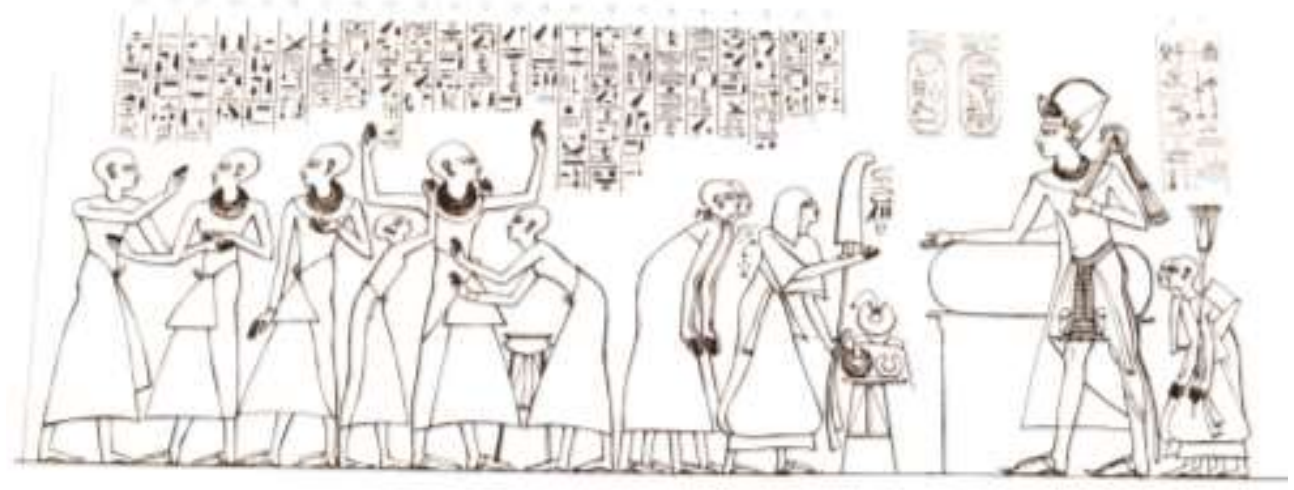

Fig. 13

Southern Side, South Wall, TT 50 of Neferhotep After R., Hari, Le Tombe Thébaine du Père Divin, pl. VI. 